3. Разумовский Э.С., Залетова Н.А., Удаление биогенных элементов из городских сточных вод// Водоснабжение и санитарная техника, 1991, №6. С. 28-30.

\title{
Легкий бетон на основе гранулированного пеностекла для энергоэффективного строительства в условиях Арктики
}

\author{
Федоров В.И., инженер, \\ Северо-Восточный федеральный университет \\ E-mail: Elley-90@mail.ru \\ Научный руководитель: \\ д.т.н., профессор Местников А.Е.
}

Текущий рост производства промышленной продукции приводит к непрерывному увеличению потребления природных ресурсов, повышению расхода энергии, увеличению образующихся отходов и загрязнению окружающей среды. Современное строительное материаловедение тесно взаимосвязано с решением таких задач как повышение эффективности производства, снижение стоимости и трудоемкости технологических процессов, рациональному использованию материальных и энергетических ресурсов [4].

Разработка энергосберегающих строительных материалов является приоритетным направлением в строительной индустрии. Именно от свойств того или иного материала зависит надежность и долговечность строительных конструкций в целом. Одним из перспективных материалов, эксплуатируемых в суровых климатических условиях, являются разновидности ячеистых композитов на основе вяжущих гидратационного твердения [1]. Однако, учитывая положительный опыт использования данных материалов, выявлен ряд недостатков. В частности, относительно низкая прочность, которая обусловлена достаточной трудоемкостью получения оптимальной пористой структуры. В первую очередь это связано с необходимостью управлять большим количеством рецептурных и технологических факторов [4].

В связи с интенсивным увеличением строительства жилых и общественных зданий в Республике Саха (Якутия), возникает необходимость в наличии конкурентоспособного конструкционно-теплоизоляционного стенового материала способного выдерживать суровые климатические условия Крайнего Севера. В первую очередь материал должен обладать пониженной плотностью, низкой теплоповодностью, высокой морозостойкостью и хорошими показателями звукопоглощающения. С учетом отечественного и мирового опыта, одним из немногочисленных материалов, отвечающих вышерассмотренным требованиям, является легкий бетон на основе гранулированного пеностекла.

Образцы изготовлены согласно требованиям современных методик подбора состава бетона. Лабораторные испытания образцов выполнены на поверенных приборах испытательного центра «Якутск-Эксперт». Исследование структуры, определение качественных и количественных показателей образцов проведены на базе инновационно-технологического центра «Энергоэффективные строительные материалы». 
В целях установления оптимального содержания пеностекла на физикомеханические показатели легкого бетона использован метод математического планирования эксперимента. Для обеспечения точности и объективности интерпретации результатов эксперимента, выбран дробный факторный эксперимент, состоящий из четырех факторов, трех уровней и 27 опытов. По результатам эксперимента выбраны составы, соответствующие опытам №13 и №19. Физикомеханические показатели образцов бетона показаны в табл. 1. Пропорции фракций пеностекла приведен в табл. 2. Расход материалов на изготовление 1 м $^{3}$ легкого бетона приведен в табл. 3.

Таблица 1

Физико-механические показатели легкого бетона на основе пеностекла

\begin{tabular}{|c|c|c|c|c|c|c|c|}
\hline \multirow{2}{*}{$\begin{array}{l}\text { Номер } \\
\text { опыта }\end{array}$} & \multicolumn{4}{|c|}{ Входные факторы } & \multicolumn{3}{|c|}{ Выходные данные } \\
\hline & $X_{1}$ & $X_{2}$ & $X_{n}$ & $x_{4}$ & $\mathbf{R}_{\text {Las }}$, MПа & $\mathbf{P}_{0}, \kappa г / \mathrm{M}^{3}$ & $\mathrm{~K}_{\mathrm{7aK}}$ \\
\hline 1 & $-1,00000$ & $-1,00000$ & $-1,00000$ & $-1,00000$ & 1,1 & 548 & 2,01 \\
\hline 2 & $-1,00000$ & $-1,00000$ & 0,00000 & 1,00000 & 2,43 & 604 & 4,02 \\
\hline 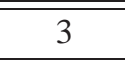 & $-1,00000$ & $-1,00000$ & 1,00000 & 0,00000 & 1,1 & 526 & 2,09 \\
\hline 4 & $-1,00000$ & 0,00000 & $-1,00000$ & 1,00000 & 2,9 & 528 & 5,49 \\
\hline 5 & $-1,00000$ & 0,00000 & 0,00000 & 0,00000 & 1,4 & 473 & 2,96 \\
\hline 6 & $-1,00000$ & 0,00000 & 1,00000 & $-1,00000$ & 0,24 & 494 & 0,49 \\
\hline 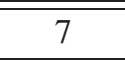 & $-1,00000$ & 1,00000 & $-1,00000$ & 0,00000 & $1,1,7$ & 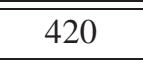 & 4,05 \\
\hline 8 & $-1,00000$ & 1,00000 & 0,00000 & $-1,00000$ & 0,37 & 464 & 0,80 \\
\hline 9 & $-1,00000$ & 1,00000 & 1,00000 & 1,00000 & 1,36 & 428 & 3,18 \\
\hline 10 & 0,00000 & $-1,00000$ & $-1,00000$ & 1,00000 & 6,37 & 682 & 9,34 \\
\hline 11 & 0,00000 & $-1,00000$ & 0,00000 & 0,00000 & 4,8 & 595 & 8,07 \\
\hline 12 & 0,00000 & $-1,00000$ & 1,00000 & $-1,00000$ & 3,57 & 584 & 6,11 \\
\hline 13 & 0,00000 & 0,00000 & $-1,00000$ & 0,00000 & 4,1 & 522 & 7,85 \\
\hline 14 & 0,00000 & 0,00000 & 0,00000 & $-1,00000$ & 2,7 & 534 & 5,06 \\
\hline 15 & 0,00000 & 0,00000 & 1,00000 & 1,00000 & 3,83 & 562 & 6,81 \\
\hline 16 & 0,00000 & 1,00000 & \begin{tabular}{|l|}
$-1,00000$ \\
\end{tabular} & $-1,00000$ & 1,83 & 484 & 3,78 \\
\hline 17 & 0,00000 & 1,00000 & 0,00000 & 1,00000 & 3,3 & 4666 & 7,08 \\
\hline 18 & 0,00000 & 1,00000 & 1,00000 & 0,00000 & 1,9 & 425 & 4,47 \\
\hline 19 & 1,00000 & $-1,00000$ & $-1,00000$ & 0,00000 & 6,3 & 616 & 10,23 \\
\hline 20 & 1,00000 & $-1,00000$ & 0,00000 & $-1,00000$ & 4,83 & 596 & 8,10 \\
\hline 21 & 1,00000 & $-1,00000$ & 1,00000 & 1,00000 & 6,1 & 688 & 8,87 \\
\hline 22 & 1,00000 & 0,00000 & $-1,00000$ & $-1,00000$ & 2,96 & 526 & 5,63 \\
\hline 23 & 1,00000 & 0,00000 & 0,00000 & 1,00000 & 4,57 & 572 & 7,99 \\
\hline 24 & 1,00000 & 0,00000 & 1,00000 & 0,00000 & 3,1 & 499 & 6,21 \\
\hline 25 & 1,00000 & 1,00000 & $-1,00000$ & 1,00000 & 3,04 & 456 & 6,67 \\
\hline 26 & 1,00000 & 1,00000 & 0,00000 & 0,00000 & 1,4 & 406 & 3,45 \\
\hline 27 & 1,00000 & 1,00000 & 1,00000 & $-1,00000$ & 0,1 & 432 & 0,23 \\
\hline
\end{tabular}


Пропорции фракций пеностекла (по массе)

\begin{tabular}{|c|c|c|c|c|}
\hline & \multicolumn{3}{|c|}{ Фракция заполнителя, мм } \\
\hline & & $\begin{array}{l}\text { Крупный } \\
\text { 7,5-20 мм }\end{array}$ & $\begin{array}{c}\text { Средний } \\
0,3-7,5 \text { мм }\end{array}$ & $\begin{array}{l}\text { Мелкий } \\
\text { 0,3-3 мм }\end{array}$ \\
\hline \multirow{3}{*}{\multicolumn{2}{|c|}{$\begin{array}{c}\text { Содержание фракции от общей массы } \\
\text { пробы, \% }\end{array}$}} & 50 & 25 & 25 \\
\hline & & 25 & 50 & 25 \\
\hline & & 25 & 25 & 50 \\
\hline \multirow{2}{*}{$\begin{array}{c}\text { Уровни } \\
\text { варьирования } \\
\text { фактора } x_{1}\end{array}$} & $\begin{array}{c}\text { Кодированное значение } \\
\text { фактора: }\end{array}$ & -1 & 0 & +1 \\
\hline & $\begin{array}{c}\text { Натуральное значение } \\
\text { фактора: }\end{array}$ & $1: 0,5: 0,5$ & $1: 2: 1$ & $1: 1: 2$ \\
\hline
\end{tabular}

В исследовании в качестве крупного и мелкого заполнителя использовано пеностекло, изготовленное ООО «Модис».

Из табл. 1 видно, что наиболее высокие показатели прочности соответствуют тем состава, у которых превалирует содержание средней и мелкой фракции. Это указывает на то, что при повышении удельной поверхности заполнителя, повышается площадь сцепления с цементной матрицей легкого бетона [2]. По результатам исследование для плотности D500 подобран состав, соответствующий опыту №13, а для плотности D600 опыт №19.

Таблица 3

Расход материалов на изготовление $1 \mathrm{~m}^{3}$ легкого бетона

\begin{tabular}{|c|c|c|c|c|c|c|c|}
\hline \multirow{2}{*}{$\begin{array}{c}\text { Проектируемый } \\
\text { класс бетона по } \\
\text { прочности при } \\
\text { сжатии }\end{array}$} & \multirow{2}{*}{$\begin{array}{c}\text { Марка } \\
\text { бетона по } \\
\text { средней } \\
\text { плотности }\end{array}$} & \multicolumn{3}{|c|}{ Расход материалов, кг/м³ } & \multirow[b]{2}{*}{ В/Ц } & \multirow{2}{*}{$\begin{array}{c}\text { Пропорции } \\
\text { фракции } \\
\text { пеностекла }\end{array}$} & \multirow{2}{*}{$\begin{array}{c}\text { Пропорции } \\
\text { сухих } \\
\text { компонентов } \\
\text { по массе } \\
\text { (Ц:П) }\end{array}$} \\
\hline & & $\begin{array}{c}\text { Цемент } \\
(\text { ( })^{1}\end{array}$ & $\begin{array}{c}\text { Пеностекло } \\
(\Pi)^{2}\end{array}$ & $\begin{array}{c}\text { Вода } \\
(\mathrm{B})^{3}\end{array}$ & & & \\
\hline B2,5 & D500 & 300 & 180 & 130 & 0,43 & $1: 2: 1$ & $1: 0,6$ \\
\hline B5 & D600 & 350 & 200 & 150 & 0,42 & $1: 1: 2$ & $1: 0,57$ \\
\hline
\end{tabular}

Таблица 4

Сравнение характеристик легкого бетона на основе пеностекла с пенобетоном автоклавного твердения

\begin{tabular}{|c|c|c|}
\hline \multirow{2}{*}{$\begin{array}{c}\text { Марка легкого бетона по } \\
\text { средней плотности }\end{array}$} & \multicolumn{2}{|c|}{ Класс бетона по прочности на сжатие } \\
\cline { 2 - 3 } & Пенобетон автоклавного твердения & Легкий бетон на основе пеностекла \\
\hline D500 & B1,5 & B2,5 \\
\hline D600 & B2 & B5 \\
\hline
\end{tabular}

Сравнительный анализ физико-механических характеристик пеностеклобетона и пенобетона автоклавного твердения показывает (табл. 4), что при одинаковой плотности преимущество имеют стеновые материалы из пеностеклобетона.

\footnotetext{
${ }^{1}$ В исследовании использован портландцемент марки ЦЕМ I 32.5Н по ГОСТ 31108-2003 «Цементы общестроительные. Технические условия»

${ }^{2}$ Соответствующая требованиям ТУ 5914-001-15068529-2006 «Универсальный пористый материал термоизоляционный УПМ «Термоизол»

3 Техническая вода по ГОСТ 23732-2011 «Вода для бетонов и строительных растворов. Технические условия»

${ }^{4}$ По данным ООО «Стройкомпозит»
} 
Легкий бетон на основе пеностекла соответствует марке по плотности D500 и D600, а по прочности при сжатии соответствует классам B2,5 и B5. Испытанные образцы легкого бетона отвечают требованиям ГОСТ 25820-2014 «Бетоны легкие. Технические условия» по всем исследованным показателям и могут быть применены в качестве энергоэффективного стенового материала, эксплуатируемого в суровых климатических условиях Арктики.

\section{Список литературы:}

1. Горлов Ю.П. Технология теплоизоляционных и акустических материалов и изделий: Учеб. для вузов. М.: Высш. школа, 1989. С. 384.

2. Иванов И.А. Легкие бетоны на искусственных пористых заполнителях: Монография. М.: Стройиздат, 1993. С. 182.

3. Майоров П.М. Бетонные смеси: рецептурный справочник для строителей и производителей строительных материалов. Ростов н/Д: Феникс, 2009. С. 461.

4. Рыбьев И.А. Строительное материаловедение: Учебное пособие для строит. спец. вузов. - 2-е изд., испр. - М.: Высшая школа, 2004.

\section{Очистка подмерзлотных вод Центральной Якутии для хозяйственно- питьевого водоснабжения}

\section{Федорова С.В., младший научный сотрудник, Институт мерзлотоведения им. П.И. Мельникова Сибирского отделения Российской академии наук, 2. Якутск E-mail: veta_f@mail.ru}

Проблема обеспечения населения Республики Саха (Якутия) питьевой водой с учетом суровых климатических условий является чрезвычайно актуальной. Неравномерное распределение населения по обширной территории Якутии диктует свои требования к организации водоснабжения. Во многих населенных пунктах Якутии организация водоснабжения из поверхностных источников невозможна ввиду их незначительной водообильности, неблагоприятной санитарной обстановки или отдаленного расположения.

На территории республики регионально распространены подмерзлотные воды, использование которых позволит максимально приблизить источники водоснабжения к конкретным водопотребителям, что значительно сократит расходы на организацию и эксплуатацию систем водоснабжения. Эти воды обладают стабильным химическим составом, не претерпевающим сезонных изменений, они надежно защищены от техногенного воздействия и безопасны в радиологическом и бактериологическом отношении. Однако, несмотря на значительные запасы подмерзлотных вод, их использование в системах питьевого водоснабжения ограниченно в связи с повышенным содержанием лития, фтора и натрия (табл.1). Отклонение от норм по содержанию перечисленных элементов вызвано геологическим строением, мерзлотногидрогеологическими условиями и литологическим составом водовмещающих пород. 